\begin{tabular}{|c|c|c|}
\hline & 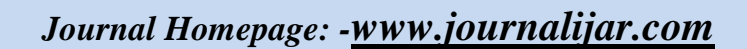 & $\begin{array}{l}\text { INTERNATIONAL JOURNAL OF } \\
\text { ADVANCED RESEARCH (JAR) }\end{array}$ \\
\hline ISSN NO. 2320-5407 & $\begin{array}{c}\text { Article DOI: } 10.21474 / \text { IJAR01/3045 } \\
\text { DOI URL: http://dx.doi.org/10.21474/IJAR01/3045 }\end{array}$ & \\
\hline
\end{tabular}

RESEARCH ARTICLE

\title{
THE OCCURRENCE AND ASSESSMENT OF AWARENESS ABOUT INTERVENTIONAL COSMETICS AMONG STUDENTS OF COLLAGE OF APPLIED SCIENCES AND COMMUNITY SERVICES IN THE UNIVERSITY OF DAMMAM SAUDI ARABIA.
}

\author{
Fatima A. Fakhroo $^{*}$, Alanood Al Thukair ${ }^{2}$, Deema Sallout ${ }^{2}$, Dina Abdulghani ${ }^{2}$, Dina AlAfandi ${ }^{2}$, Hawra \\ AlJohi $^{2}$, Hessa AlOtaibi ${ }^{2}$, Lina AbuGharara ${ }^{2}$, Maryam K. Ebrahim ${ }^{3}$, Sarah AlArifi ${ }^{2}$, and Sarah AlHajri ${ }^{2}$ \\ 1. Bahrain Defense Force Hospital, Bahrain. \\ 2.King Fahd University Hospital, Saudi Arabia. \\ 3.Salmaniya Medical Complex, Bahrain.
}

\section{Manuscript Info}

Manuscript History

Received: 30 November 2016

Final Accepted: 28 December 2016

Published: January 2017

\begin{abstract}
Seeing how the number of teenagers undergoing cosmetic surgeries is on the rise, and how most people undergoing cosmetic interventions are unaware of their consequences.

Objectives: This study assessed the awareness and estimated the occurrence of cosmetic surgeries among 530 female students from the University of Dammam's College of Applied Sciences and Community Service. It also aimed at assessing the association between age and future cosmetic surgeries, as well as determining the prevailing body image, BMI, and attitude, and their relationship with cosmetic surgeries among these students.

Methodology: A stratified random sampling method with proportionate allocation was conducted.

Results: About $40 \%$ of the females above 15 years old reported had undergoing a cosmetic surgical intervention, with hair removal by laser being the most frequently preformed. Also, 59\% of the students had a body mass index within the normal range.In addition, mean total knowledge score for those who "did not perform surgery" is 11.22 . While, mean total knowledge score for those who "performed surgery" is 12.18 .

Conclusion: In general, there was an increased awareness about cosmetic interventions. The study also found that previous conductance of cosmetic surgery substantially affected the level of knowledge about these procedures. Further studies are required to determine the reasons behind seeking these cosmetic interventions.
\end{abstract}

Copy Right, IJAR, 2016,. All rights reserved. 
Cosmetic surgery is usually performed to correct a physical abnormality or to enhance an otherwise normal physical feature and, therefore, improve a person's appearance. In the not so distant past, it was confined only to surgery that was absolutely necessary to the health and well-being of the patient, such as skin-grafting for serious burn injuries, repairing a broken nose or jaw, or treating an unseemly birthmark across the face. Cosmetic surgery was first used regularly after World War I, when treatment and reconstruction of war injuries gave hope to young soldiers ${ }^{[1]}$. Cosmetic surgery has increased dramatically in popularity over the past 10 years ${ }^{[2]}$, and it is constantly on the rise, seeing how more and more people are turning to cosmetic surgeries in their search for physical perfection.

According to the International Society of Aesthetic Plastic Surgery (ISAPS), two studies were conducted in 2010 and 2011 to determine the top 25 countries by total number of cosmetic procedures showed that Saudi Arabia ranked as $23^{\text {rd }}, 22^{\text {nd }}$ top country worldwide respectively, by total number of 45,398 procedures in 2010 and 46,962 procedures in $2011^{[3,4]}$.

In Saudi Arabia and worldwide, Lipoplasty was the most prevalent cosmetic surgery; $19.9 \%$ of all cosmetic surgeries worldwide in 2011 were lipoplasties, and 9,601 of them were preformed in Saudi Arabia. The second most prevalent surgery was breast augmentation, comprising $18.6 \%$ of cosmetic surgeries worldwide, with 6,424 surgeries preformed in Saudi Arabia in 2011. Rhinoplasty was the third most prevalent cosmetic surgery in Saudi Arabia, with 5,630 procedures preformed in 2011. There were also, 4,984 blepharoplasties and 3,652 abdominoplasties performed in Saudi Arabia in $2011^{[4]}$.

Almost all plastic surgeries have risks, and these risks vary in their severity and their duration. For instance, temporary numbness or loss of feeling at the site of the incision is fairly common in face-lifts and tummy tucks, though it's rarely permanent. Numbness after breast surgeries of any type is the most common. Loss of sensation in the nipple in particular occurs anywhere from $10 \%$ to $70 \%$ of the time, depending on the type of procedure. Another example is a seroma, which is a collection of watery body fluids that occurs most often in tummy tucks. It's common enough that many surgeons take preventative measures by inserting a drain during surgery. Tissue necrosis due to surgical manipulation is inevitable after any procedure, though risks increase dramatically if the patient is a smoker. Infections are rare in plastic surgery patients, since most patients are healthy to begin with. However, when they do happen, they can spread quickly and must be stopped immediately ${ }^{[5]}$.

The number of plastic surgeries is on the rise, and many of the people undergoing these procedures are unaware of their risks. Many doctors and institutions are taking advantage of these people and treating this sector as a booming business. This resulted in the percentage of teenagers undergoing these procedures to rise to a total of $2 \%$ of all procedures, adding up to about 230,617 procedures per year, including laser hair removal $(69,434$ procedures), rhinoplasty $(33,892)$, and Botox injections $(16,160)$. There are also about 8,892 teenage girls having breast implants $[6]$.

Moreover, in the field of cosmetic plastic surgery, common deaths are related to anesthesia with the highest probability of occurrence being 1 out of 13,000 and lowest 1 out of 300,000. Liposuction related surgery deaths are estimated to happen in every 5,000 cases due to the usage of general anesthesia. Tummy tucks accounted for 1 out of every 500 cases. For the elderly that undergo face-lift procedures, their risks are 1 in every 600 cases ${ }^{[7]}$.

Based on all of what we mentioned above, we decided to conduct this study among the University of Dammam female students to assess their awareness of cosmetic surgeries and to estimate the occurrence of cosmetic surgeries among them.

\section{Objectives:-}

General objectives:to assess the awareness of university students on cosmetic interventions, and estimate the occurrence of cosmetic surgeries among university students.

Specific objectives: To assess the association between age and future cosmetic surgeries among university students. Also, to determine the prevailing body image, BMI, attitude and their relationship with cosmetic surgeries.

\section{Methodology:- Setting:-}


This cross-sectional study aimed to estimate the occurrence of cosmetic interventions and to assess the level of awareness about them among female students of the college of applied sciences, University of Dammam, Khobar, Saudi Arabia. This college was selected because of its accessibility and proximity to the survey conductors.

Research was conducted in a 2 weeks period. Started on 24/11/2013 and ended on 5/12/2013.

\section{Participants:-}

The target population consisted of 530 female students from the College Of Applied sciences, from 1st level to 8th level. The participants' ages fill in the range of 17 to 25 year old.Almost all the participants were Saudi nationals.

\section{Procedure:-}

Survey conductors followed a random stratified sampling method while distributing the questionnaires among the students of the college of applied sciences. All students anonymously completed a self-admitted questionnaire developed to assess the knowledge and rate of occurrence of interventional cosmetic surgeries. The questionnaire contained questions inquiring about the procedures they or any of their female relative had undergone. The participants were also asked whether they wanted to undergo cosmetic surgery or not, and which specific procedure they would like to have. Participants' attitude about cosmetic surgeries was assessed by a 1-4 scale, 1 being "strongly disagree", and 4 being "strongly agree". The rest of the questionnaire consisted of multiple-choice questions regarding various types of cosmetic surgeries and their procedure and subsequent side affect. These multiple-choice questions were aiming to estimate the total knowledge of university students concerning cosmetic surgeries. After collecting the questionnaires, the students were accompanied by the survey collectors to a scale where their weights and heights were accurately measured.

\section{Ethical Consideration:-}

An approval letter was addressed to the Dean of each college included in the research. Brief explanation of the study was conducted to each participated student and answering the questionnaire implied the consent. Confidentiality and anonymity was assured for all the information gathered. Participation in the research was voluntary.

\section{Statistical Design:-}

The statistical analysis was done using SPSS-Ver.20 statistical software package. All data collected was entered to SPSS. It was analyzed and categorized by medical students involved in research. We calculated the total knowledge score by adding the score of correct answers, yielding a maximum score of 30 and categorized into: $1=$ poor knowledge (<15), 2= average knowledge (15-23) and 3= good knowledge (> 23). Body Mass Index was calculated by the equation: weight $(\mathrm{kg}) /(\text { height }(\mathrm{m}))^{2}$, and categorized into $1=$ underweight $(<18.5), 2=$ normal $(18.5-24.9), 3=$ overweight (25-29.9), 4=obese (30-39.9), and $5=$ morbidly obese $(\geq 40)$.

Data was represented by using descriptive statistics in the form of numbers and percentages for qualitative variables (Categorized BMI, Body Image, Past surgery Conductance, Attitude, Family Monthly Income, Age Groups and Future Surgery Conductance). Mean \pm standard deviation (SD) was applied for quantitative variables (Total Knowledge Score, Correct Answers and occurrence for each surgery). Frequency tables and cross tables were used. Also, statistical tests were used like: t-test and chi-square test. T-test was used for associating one qualitative variable and a quantitative variable, for example, the distribution of the mean total knowledge score (quantitative, dependent variable) by surgery conductance (Independent variable). Furthermore, the chi-square test was used for finding the relationship between two qualitative variables as between body image and BMI). Finally, the significance of all statistical tests was set at a P-value of 0.05 .

\section{Results:-}

Table 1 discusses the demographic characteristics of the data collected from the 530 students. Variable chosen where: level, age, marital status, family monthly income, and the educational level of the mother and the father. First, the percentage of students who were 25 year old was the lowest $(1 \%)$, on the other hand, the percentage of students who where 20 year old was the highest $(22.4 \%)$. Second, $86.6 \%$ of students were unmarried, while $13.4 \%$ were married showing that the majority of the students are not married. Third, $60.6 \%$ has a family monthly income greater than $15000 \mathrm{SR}$. This represents the highest percentage. This is followed by those who have a family monthly income ranges between 5000-15000 SR, representing 36.3\%. In addition, the percentage of parents who had an educational level of "university and above" was $49.8 \%$. This represents the highest proportion out of the 4 levels of education. Finally, the association between the educational level of the mother and the father with knowledge score showed no significance. 
Table 2 shows the association between body image and body mass index. In general, the university students are aware of their current weight. 59\% of the students had a body mass index within the normal range. Furthermore, $21.1 \%$ of the students were overweight, and this is considered to be slightly elevated. Only $0.8 \%$ of students were morbidly obese. Finally, $83.5 \%$ of the students who fall within the normal range of BMI considered themselves normal, and they were the most accurate.

Table 3 shows association between conductance of surgery-attitude and monthly income. First, concerning the attitude the following was found. $77.79 \%$ of the students accepted undergoing surgeries for medical reasons. Among them, $49 \%$ have already undergone surgery. In addition, $34.9 \%$ of those who believe that undergoing cosmetic surgeries is "Totally unaccepted" performed surgery. They might done hair removal by laser or skin pealing which they didn't consider it a cosmetic intervention to change the appearance. Second, concerning the monthly income the following was found. About $65.5 \%$ of students who had undergone cosmetic surgeries had a monthly family income of 15000 SR or more, followed by $33.3 \%$ for whom who had a monthly family income falling between 5000-15000 SR. As a result, this strongly suggests the substantial role of general financial state on conductance of surgery.

Table 4 shows the distribution of the mean total knowledge score by conductance of surgery. The mean total knowledge score of those who had undergone surgery $=12.8, \mathrm{SD}=3.172$, this means that about $68 \%$ of total knowledge scores of those who had undergone surgery are between (9.6-15.97). On the other hand, the mean total knowledge score of those who had not undergone surgery $=11.22, \mathrm{SD}=3.207$, this means that about $68 \%$ of total knowledge scores of those who had not undergone surgery are between (8.01-14.43). Also, T-Test P-value 0.001 highly significant. As a result, past experience of cosmetic surgery plays a role in the knowledge about cosmetic interventions.

Table 5 shows the assessment of correct answers (Questions 34 - 63) by frequency and valid percentage. Question about "Indications of skin abrasion" was the most common correctly answered question by $70.9 \%$ of students. Next, the question concerning "Effective duration of Botox" was correctly answered by $65.8 \%$ of the students. Finally, the question with the third highest correct answer was about "Indications of plastic nose surgery" constituting $64.3 \%$ of the students. In contrast, question regarding "Function of Botox injections for facial wrinkles" was the least question answered correctly,only by $11.1 \%$ of student. (Low frequency of correct answer might be due requirement of pure medical knowledge in order to answer the question, since the answer was: the Botox exerts it effect chemically by inhibiting the postganglionic synapse innervating the muscles of facial expression). In addition, by categorizing the questions according to the cosmetic intervention they assess, and calculating the average of both the frequency and the valid percent, the following results were found to be: Questions assessing the knowledge about skin peeling, skin abrasion, and the hair removal by laser got the highest average valid percentage $(62.1 \%, 46.7 \%$, and $45.2 \%)$ respectively.

Table 6 shows the total Occurrence of each Cosmetic Intervention Among Females above 15 years old.40.5\% of the total females had undergone a cosmetic intervention. "Hair removal by laser" is the most common cosmetic intervention done among the total female population of the sample with the highest percentage of $22.8 \%$. Moreover, the second common cosmetic intervention was "Skin abrasion", conducted by $4.24 \%$ of students. Finally, the third common cosmetic intervention was "Skin care with laser", conducted by $3.66 \%$ students.

Table 7 shows the association between age group and future surgery. The percentage of students who wish to undergo future cosmetic surgery increases with age, being $41.7 \%$ in students aged from 23-25 year old.

Table 1:-Demographic characteristics of data collected from 530 female students in the University of Dammam College of Applied Studies and Community Services

\begin{tabular}{|c|c|c|c|}
\hline \multicolumn{2}{|c|}{ Demographic characteristics } & No. of females=530 & Percentage \\
\hline \multirow{3}{*}{ Year } & $1^{\text {st }}$ year & 149 & $28.1 \%$ \\
\cline { 2 - 4 } & $2^{\text {nd }}$ year & 146 & $27.5 \%$ \\
\cline { 2 - 4 } & $3^{\text {rd }}$ year & 113 & $21.3 \%$ \\
\cline { 2 - 4 } & $4^{\text {th }}$ year & 122 & $23.0 \%$ \\
\cline { 2 - 4 } & Total & 530 & $100 \%$ \\
\hline Age & 17 & 8 & $1.5 \%$ \\
\hline
\end{tabular}




\begin{tabular}{|c|c|c|c|}
\hline & 18 & 75 & $14.3 \%$ \\
\hline & 19 & 114 & $21.7 \%$ \\
\hline & 20 & 118 & $22.4 \%$ \\
\hline & 21 & 103 & $19.6 \%$ \\
\hline & 22 & 66 & $12.5 \%$ \\
\hline & 23 & 30 & $5.7 \%$ \\
\hline & 24 & 7 & $1.3 \%$ \\
\hline & 25 & 5 & $1.0 \%$ \\
\hline & Total & $526 *$ & $100 \%$ \\
\hline \multirow[t]{3}{*}{ Marital status } & Married & 71 & $13.4 \%$ \\
\hline & Not married & 459 & $86.6 \%$ \\
\hline & Total & 530 & $100 \%$ \\
\hline \multirow[t]{4}{*}{ Monthly income } & Less than 5000 & 16 & $3.0 \%$ \\
\hline & $5000-15000$ & 191 & $36.3 \%$ \\
\hline & More than 15000 & 319 & $60.6 \%$ \\
\hline & Total & $526 *$ & $100 \%$ \\
\hline \multirow[t]{5}{*}{ Educational level of the mother } & University or above & 222 & $42.0 \%$ \\
\hline & Secondary & 173 & $32.7 \%$ \\
\hline & Middle & 71 & $13.4 \%$ \\
\hline & Primary or below & 63 & $11.9 \%$ \\
\hline & Total & $529 *$ & $100 \%$ \\
\hline \multirow[t]{5}{*}{ Educational level of the father } & University or above & 304 & $57.6 \%$ \\
\hline & Secondary & 148 & $28.0 \%$ \\
\hline & Middle & 49 & $9.3 \%$ \\
\hline & Primary or below & 27 & $5.1 \%$ \\
\hline & Total & $528 *$ & $100 \%$ \\
\hline
\end{tabular}

Table 2:- Association Between Body Image and Body Mass Index (BMI)

\begin{tabular}{|c|c|c|c|c|c|c|c|c|}
\hline \multirow{2}{*}{\multicolumn{2}{|c|}{$\begin{array}{c}\text { Body Image: } \\
\text { Do you } \\
\text { Consider yourself } \\
\text { of normal weight? }\end{array}$}} & \multicolumn{5}{|c|}{ BMI Category } & \multirow{2}{*}{$\begin{array}{c}\text { Total } \\
(\mathrm{n}=522)^{*}\end{array}$} & \multirow{3}{*}{$\begin{array}{c}\text { Chi- } \\
\text { square } \\
(\mathrm{P}) \\
\text { value } \\
.000\end{array}$} \\
\hline & & \multirow{2}{*}{$\begin{array}{c}\text { Underweight } \\
(<18.5) \\
37\end{array}$} & \multirow{2}{*}{$\begin{array}{c}\text { Normal } \\
(18.5- \\
24.9) \\
23\end{array}$} & \multirow{2}{*}{$\begin{array}{c}\text { Overweight } \\
(25-29.9) \\
0\end{array}$} & \multirow{2}{*}{$\begin{array}{c}\text { Obesity } \\
(30- \\
39.9) \\
0\end{array}$} & \multirow{2}{*}{$\begin{array}{c}\text { Morbid } \\
\text { Obesity } \\
(\geq 40) \\
0\end{array}$} & & \\
\hline Underweight & No. & & & & & & 60 & \\
\hline & $\%$ & $61.7 \%$ & $38.3 \%$ & $0 \%$ & $0 \%$ & $0 \%$ & $100 \%$ & \\
\hline \multirow[t]{2}{*}{ Normal } & No. & 19 & \multirow{2}{*}{$\begin{array}{c}212 \\
83.5 \% \\
\end{array}$} & 21 & 1 & 1 & 254 & \\
\hline & $\%$ & $7.5 \%$ & & $8.3 \%$ & $0.4 \%$ & $0.4 \%$ & $100 \%$ & \\
\hline \multirow[t]{2}{*}{ Overweight } & No. & 0 & 70 & 85 & 26 & 0 & 181 & \\
\hline & $\%$ & 0 & $38.7 \%$ & $47 \%$ & $14.4 \%$ & $0 \%$ & $100 \%$ & \\
\hline \multirow[t]{2}{*}{ Obese } & No. & 0 & 3 & 4 & 17 & 3 & 27 & \\
\hline & $\%$ & $0 \%$ & $11.1 \%$ & 14.8 & $63 \%$ & $11.1 \%$ & $100 \%$ & \\
\hline \multirow[t]{2}{*}{ Total } & No. & 56 & \multirow[t]{2}{*}{308} & \multirow[t]{2}{*}{110} & 44 & \multirow[t]{2}{*}{4} & $522 *$ & \\
\hline & $\%$ & $10.7 \%$ & & & $8.4 \%$ & & $100 \%$ & \\
\hline
\end{tabular}

Table 3:-Association Between Conductance of surgery-attitude and monthly income

\begin{tabular}{l|l} 
Attitude & Surgery conductance
\end{tabular}




\begin{tabular}{|c|c|c|c|c|c|}
\hline & & $\begin{array}{c}\text { Perform } \\
\text { surgery }\end{array}$ & $\begin{array}{l}\text { Did not perform } \\
\text { surgery }\end{array}$ & $\begin{array}{c}\text { Total } \\
(\mathrm{n}=527)\end{array}$ & (p) value \\
\hline \multirow[t]{2}{*}{ Totally unaccepted } & No. & 15 & 28 & 43 & \multirow[t]{10}{*}{.023} \\
\hline & $\%$ & $34.9 \%$ & $65.1 \%$ & $100 \%$ & \\
\hline \multirow[t]{2}{*}{ Accepted for medical reasons } & No. & 201 & 209 & 410 & \\
\hline & $\%$ & $49 \%$ & $51 \%$ & $100 \%$ & \\
\hline \multirow[t]{2}{*}{ Accepted for cosmetic reasons } & No. & 45 & 26 & 71 & \\
\hline & $\%$ & $63.4 \%$ & $36.6 \%$ & $100 \%$ & \\
\hline \multirow{2}{*}{$\begin{array}{l}\text { Accepted for changing features to look like } \\
\text { celebrities }\end{array}$} & No. & 1 & 2 & 3 & \\
\hline & $\%$ & $33.3 \%$ & $66.7 \%$ & $100 \%$ & \\
\hline \multirow[t]{2}{*}{ Total } & No. & 262 & 265 & $527 *$ & \\
\hline & $\%$ & $49.7 \%$ & $50.3 \%$ & $100 \%$ & \\
\hline \multirow{2}{*}{\multicolumn{2}{|c|}{ Monthly Income }} & \multicolumn{3}{|c|}{ Surgery Conductance } & \multirow{2}{*}{$\begin{array}{l}\text { Chi-square } \\
\text { (P) value }\end{array}$} \\
\hline & & $\begin{array}{l}\text { Perform } \\
\text { surgery }\end{array}$ & $\begin{array}{l}\text { Did not perform } \\
\text { surgery }\end{array}$ & $\begin{array}{c}\text { Total } \\
(\mathrm{n}=523)\end{array}$ & \\
\hline Less than 5000 & $\begin{array}{c}\text { No. } \\
\%\end{array}$ & $\begin{array}{c}3 \\
18.8 \%\end{array}$ & $\begin{array}{c}13 \\
81.2 \%\end{array}$ & $\begin{array}{c}16 \\
100 \%\end{array}$ & \multirow[t]{4}{*}{.008} \\
\hline $5000-15000$ & $\begin{array}{c}\text { No. } \\
\%\end{array}$ & $\begin{array}{c}87 \\
45.8 \% \\
\end{array}$ & $\begin{array}{c}103 \\
54.2 \%\end{array}$ & $\begin{array}{c}190 \\
100 \% \\
\end{array}$ & \\
\hline More than 15000 & $\begin{array}{c}\text { No. } \\
\%\end{array}$ & $\begin{array}{c}171 \\
53.9 \%\end{array}$ & $\begin{array}{c}146 \\
46.1 \%\end{array}$ & $\begin{array}{c}317 \\
100 \%\end{array}$ & \\
\hline Total & $\begin{array}{c}\text { No. } \\
\%\end{array}$ & $\begin{array}{c}261 \\
49.9 \%\end{array}$ & $\begin{array}{c}262 \\
50.1 \%\end{array}$ & $\begin{array}{l}523 * \\
100 \%\end{array}$ & \\
\hline \multicolumn{6}{|c|}{$*$ There are missing data (Total sample size $=530$ ) } \\
\hline
\end{tabular}

Table 4:-The Distribution of the Mean Total Knowledge Score by Conductance of Surgery

\begin{tabular}{|c|c|c|c|c|c|}
\hline & Surgery Conductance & $\mathrm{n}=527 *$ & $\begin{array}{c}\text { Mean } \\
\text { (Total Score = 30) }\end{array}$ & $\begin{array}{c}\text { St. Deviation } \\
\mathrm{P} \text { value }\end{array}$ & 0.001 \\
\hline \multirow{2}{*}{$\begin{array}{c}\text { Knowledge } \\
\text { score }\end{array}$} & No surgery & 265 & 11.22 & 3.207 & 3.172 \\
\cline { 2 - 6 } & Perform surgery & 262 & 12.18 & \\
\hline
\end{tabular}

Table 5:-Assessment of Correct Answers (Questions 34 - 63) by Frequency and Valid Percentage

\begin{tabular}{|c|c|c|c|}
\hline $\begin{array}{c}\text { Categorizing Questions according to Knowledge } \\
\text { they Access }\end{array}$ & Question & Frequency & $\begin{array}{c}\text { Valid } \\
\text { Percent }\end{array}$ \\
\hline \multirow[t]{5}{*}{ Botox and Fillers } & $\begin{array}{l}\text { 34-Function of Botox injections for } \\
\text { facial wrinkles }\end{array}$ & 59 & $11.1 \%$ \\
\hline & 35-Effective duration of Botox & 349 & $65.8 \%$ \\
\hline & 36-Indications of fillers & 310 & $58.5 \%$ \\
\hline & 37-Complications of fillers & 76 & $14.4 \%$ \\
\hline & Average & $\mathbf{1 9 8 . 5}$ & $37.5 \%$ \\
\hline \multirow[t]{3}{*}{ Hair removal by laser } & $\begin{array}{l}\text { 38-Best candidate for hair removal } \\
\text { by laser }\end{array}$ & 322 & $60.8 \%$ \\
\hline & $\begin{array}{c}\text { 39-Side effects of hair removal by } \\
\text { laser }\end{array}$ & 156 & $29.5 \%$ \\
\hline & Average & 239 & $45.2 \%$ \\
\hline \multirow[t]{2}{*}{ Skin care by laser } & 40-Indications of laser for skin care & 175 & $33.1 \%$ \\
\hline & Average & 175 & $33.1 \%$ \\
\hline \multirow[t]{3}{*}{ Skin abrasion } & 41-Indications of skin abrasion & 375 & $70.9 \%$ \\
\hline & 42-Complications of skin abrasion & 119 & $22.5 \%$ \\
\hline & Average & 247 & $46.7 \%$ \\
\hline Skin peeling & $\begin{array}{l}\text { 43-Instructions for chemical face } \\
\text { skin peeling }\end{array}$ & 323 & $60.9 \%$ \\
\hline
\end{tabular}




\begin{tabular}{|c|c|c|c|}
\hline & $\begin{array}{l}\text { 44-Instructions for chemical face } \\
\text { skin peeling }\end{array}$ & 334 & $63.3 \%$ \\
\hline & Average & 328.5 & $62.1 \%$ \\
\hline \multirow[t]{8}{*}{ Bariatric Surgeries } & $\begin{array}{l}\text { 45-Indication of bariatric surgeries } \\
\text { for weight management }\end{array}$ & 198 & $37.4 \%$ \\
\hline & $\begin{array}{c}\text { 46-Contraindications of bariatric } \\
\text { surgery }\end{array}$ & 88 & $16.6 \%$ \\
\hline & $\begin{array}{l}\text { 47-Medical preparation for bariatric } \\
\text { surgery }\end{array}$ & 260 & $49.1 \%$ \\
\hline & $\begin{array}{l}\text { 48-Bariatric surgery suitable for } \\
\text { sweet lovers }\end{array}$ & 92 & $17.4 \%$ \\
\hline & $\begin{array}{c}\text { 49-Risk factor during bariatric } \\
\text { surgery }\end{array}$ & 331 & $62.5 \%$ \\
\hline & $\begin{array}{c}\text { 50-Bariatric surgery causing } \\
\text { malabsorption }\end{array}$ & 183 & $34.6 \%$ \\
\hline & $\begin{array}{l}\text { 51-Regular type of food intake after } \\
\text { gastric bypass }\end{array}$ & 223 & $42.2 \%$ \\
\hline & Average & 196.4 & $37.1 \%$ \\
\hline \multirow[t]{3}{*}{ Breast augmentation } & $\begin{array}{c}\text { 52-Contraindications of breast } \\
\text { augmentation }\end{array}$ & 106 & $20.0 \%$ \\
\hline & $\begin{array}{c}\text { 53-Complications of breast } \\
\text { augmentation }\end{array}$ & 131 & $24.7 \%$ \\
\hline & Average & 118.5 & $22.4 \%$ \\
\hline \multirow[t]{3}{*}{ Liposuction } & 54-Indications of liposuction & 120 & $22.6 \%$ \\
\hline & 55-Complications of liposuction & 281 & 53.0\% \\
\hline & Average & 200.5 & $\mathbf{3 7 . 8 \%}$ \\
\hline \multirow[t]{3}{*}{ Abdominoplasty } & 56-Indications of abdominoplasty & 273 & $51.5 \%$ \\
\hline & $\begin{array}{c}\text { 57-Complications of } \\
\text { abdominoplasty }\end{array}$ & 114 & $21.5 \%$ \\
\hline & Average & 193.5 & $36.5 \%$ \\
\hline \multirow[t]{3}{*}{ Nose surgery } & $\begin{array}{l}\text { 58-Nose surgery considered as } \\
\text { cosmetic }\end{array}$ & 97 & $18.3 \%$ \\
\hline & $\begin{array}{c}\text { 59-Indications of plastic nose } \\
\text { surgery }\end{array}$ & 341 & $64.3 \%$ \\
\hline & Average & 219 & $41.3 \%$ \\
\hline \multirow[t]{3}{*}{ Blepharoplasty } & 60-Main reason for blepharoplasty & 316 & $59.6 \%$ \\
\hline & $\begin{array}{c}\text { 61-Contraindication of } \\
\text { blepharoplasty }\end{array}$ & 91 & $17.2 \%$ \\
\hline & Average & 203.5 & $38.4 \%$ \\
\hline \multirow[t]{3}{*}{ Breast lift } & $\begin{array}{c}\text { 62-Instructions for patients after } \\
\text { breast lift }\end{array}$ & 296 & $56.0 \%$ \\
\hline & 63-Procedure of breast lift & 85 & $16.0 \%$ \\
\hline & Average & 190.5 & $36 \%$ \\
\hline
\end{tabular}




\begin{tabular}{|c|c|c|}
\hline Cosmetic Intervention & Total Number of Females & Percentage \\
\hline Breast augmentation & 7 & $0.3 \%$ \\
\hline Breast lift & 3 & $0.14 \%$ \\
\hline Liposuction & 12 & $0.57 \%$ \\
\hline Abdominoplasty & 8 & $0.38 \%$ \\
\hline Rhinoplasty & 17 & $0.8 \%$ \\
\hline Blepharoplasty & 5 & $0.23 \%$ \\
\hline Gastric banding & 6 & $0.28 \%$ \\
\hline Sleeve gastrectomy & 6 & $0.28 \%$ \\
\hline Gastric bypass & 8 & $0.38 \%$ \\
\hline Botox & 33 & $1.57 \%$ \\
\hline Hair removal with laser & 479 & $22.8 \%$ \\
\hline Skin care with laser & 77 & $3.66 \%$ \\
\hline Skin abrasion & 89 & $4.24 \%$ \\
\hline Chemical skin peeling & 53 & $2.52 \%$ \\
\hline Fillers & 33 & $1.57 \%$ \\
\hline Other cosmetic surgeries & 16 & $0.76 \%$ \\
\hline Total & 852 & $40.5 \%$ \\
\hline
\end{tabular}

Table 6:-Total Occurrence of each Cosmetic Intervention Among Females above 1

Table 7:-Association Between Age Groups and Future Surgery

\begin{tabular}{|c|c|c|c|c|c|}
\hline \multirow[t]{2}{*}{ Age Groups } & \multicolumn{3}{|c|}{ Future Surgery } & \multirow{2}{*}{$\begin{array}{c}\text { Total } \\
(\mathrm{n}=511)\end{array}$} & \multirow{2}{*}{$\begin{array}{c}\text { Chi- } \\
\text { Square } \\
\text { (P-value) }\end{array}$} \\
\hline & \multicolumn{2}{|c|}{ no wish } & wish & & \\
\hline \multirow[t]{2}{*}{ 17-19 year old girls } & Count & 161 & 32 & 193 & \\
\hline & $\begin{array}{l}\% \text { within age } \\
\text { groups }\end{array}$ & $83.4 \%$ & $16.6 \%$ & $100.0 \%$ & \multirow[t]{6}{*}{.003} \\
\hline \multirow{2}{*}{$20-22$ year old girls } & Count & 225 & 57 & 282 & \\
\hline & $\begin{array}{l}\% \text { within age } \\
\text { groups }\end{array}$ & $79.8 \%$ & $20.2 \%$ & $100.0 \%$ & \\
\hline \multirow[t]{2}{*}{$23-25$ year old girls } & Count & 21 & 15 & 36 & \\
\hline & $\begin{array}{l}\% \text { within age } \\
\text { groups }\end{array}$ & $58.3 \%$ & $41.7 \%$ & $100.0 \%$ & \\
\hline \multirow[t]{2}{*}{ Total } & Count & 407 & 104 & 511 & \\
\hline & $\begin{array}{l}\% \text { within age } \\
\text { groups }\end{array}$ & $79.6 \%$ & $20.4 \%$ & $100.0 \%$ & \\
\hline
\end{tabular}

\section{Conclusion:-}

This study was conducted to assess university female students awareness about cosmetic interventions, carries quite interesting findings regarding this concern. About $40 \%$ of participants reported undergoing a surgical cosmetic intervention, with hair removal by laser being the most common procedure conducted among collage girls. The study results show an increasing awareness about cosmetic interventions. Interestingly, previous conductance of cosmetic surgery substantially affects the level of knowledge about these procedures. There is a need for further studies deeply assessing the level of knowledge about cosmetic interventions and inquiring the reasons for seeking out these procedures.

\section{Recommendations:-}

It is highly recommended to conduct further studies and researches to collect more data and to ensure results.

Furthermore, health care providers are recommended to increase public awareness about cosmetic plastic surgeries especially its complication.

Finally, higher authorities should set strict laws and penalties to prevent malpractice.

\section{Acknowledgement:-}


We would like to thank University of Dammam, specifically Department of Family and Community Medicine for giving us the opportunity to do this study.

Finally, special thanks to University of Dammam, College of Medicine, Batch 211 for their collaboration in collecting the questionnaires.

\section{References:-}

1. wiseGEEK. What is cosmetic surgery?.[Online]. available from: http://www.wisegeek.org/what-is-cosmeticsurgery.htm . [Accessed 3rd December 2013].

2. Cleveland clinic .cosmetic surgery: Today and in the future . [Online]. available from:http://my.clevelandclinic.org/services/Cosmetic_Surgery/hic_Cosmetic_Surgery_Today_and_in_the_Futu re.aspx . [Accessed 3rd December 2013].

3. International Society of Aesthetic Plastic Surgery . ISAPS International Survey on Aesthetic/Cosmetic Procedures Performed in 2010. [Online]. available from: http://www.isaps.org/Media/Default/globalstatistics/ISAPS-Results-Procedures-2010.pdf [Accessed 3rd December 2013].

4. International Society of Aesthetic Plastic Surgery . ISAPS International Survey on Aesthetic/Cosmetic Procedures Performed in 2011. [Online]. available from: http://www.isaps.org/Media/Default/globalstatistics/ISAPS-Results-Procedures-2011.pdf [Accessed 3rd December 2013].

5. Marcus M. Forbes. Ten Plastic Surgery Risks You Need To Know. [Online] 2007. Available from:http://www.forbes.com/2007/10/09/health-surgery-risks-forbeslife-cx_mlm_1010health.html [Accessed 28th November 2013].

6. The Guardian. US Plastic Surgery Statistics. [Online] 2011. Available From: http://www.theguardian.com/news/datablog/2011/jul/22/plastic-surgery-medicine [Accessed 28th November 2013].

7. Mark A. Kaire .Cosmetic Plastic Surgery Death Statistics. [Online]. available from: http://floridamedicalmalpracticelaws.com/cosmetic-plastic-surgery-death-statistics/ . [Accessed 3rd December 2013]. 